\title{
GOMMENTS
}

\section{GONSTITUTIONAL ALTERNATIVES TO PLEA BARGAINING: A NEW WAIVE}

\section{INTRODUCTION}

The right to a trial by jury, a right guaranteed by the sixth amendment, ${ }^{1}$ has been seriously undermined by the huge criminal caseload and the limited resources of our judicial system. Jury trial has become the exception rather than the rule as guilty pleas dispose of the vast majority of criminal cases without trial. ${ }^{2}$ Plea bargaining, the system whereby criminal defendants are given inducements in the form of reduced charges or lighter sentences in exchange for pleading guilty, has been accepted as a necessary evil and upheld by the Supreme Court as a constitutional method of determining guilt. ${ }^{3}$ Some commentators, however, dispute the Supreme Court's view, arguing that plea bargaining infringes a criminal defendant's absolute right to a trial by jury, and thus is unconstitutional. These commentators urge that the system provide resources adequate to permit the exercise of this constitutional right. ${ }^{\mathrm{s}}$

Alternatives to increasing resources do, however, exist. Several major American cities have tried using criminal bench trials for the same purpose that most other cities have used guilty pleas: as an inexpensive alternative to jury trials. ${ }^{6}$ In these jurisdictions, the state promises to

1 U.S. CoNST. amend VI.

- Alschuler, Implementing the Criminal Defendant's Right to Trial: Alternatives to the Plea Bargaining System, 50 U. CHI. L. REv. 931, 935 n.36 (1983); Cramer, Rossman \& McDonald, The Judicial Role in Plea-Bargaining, in Plea BargainIng 139 (W. McDonald \& J. Gramer eds. 1980); Halberstam, Towards Neutral Principles in the Administration of Criminal Justice: A Critique of Supreme Court Decisions Sanctioning the Plea Bargaining Process, 73 J. CRIM. L. \& CRImINology 1, 2 (1982).

See, e.g., Santobello v. New York, 404 U.S. 257, 261 (1971); North Carolina v. Alford, 400 U.S. 25, 31 (1970); Brady v. United States, 397 U.S. 742, 747-48 (1970).

- Alschuler, The Supreme Court, the Defense Attorney, and the Guilty Plea, $47 \mathrm{U}$. Colo. L. Rev. 1, 63-65 (1975); Note, The Unconstitutionality of Plea Bargaining, 83 HARV. L. Rev. 1387 (1970).

- Note, supra note 4, at 1411; see also Alschuler, supra note 2 (proposing other alternatives, such as jury waiver systems).

- For studies of these jurisdictions, see generally J. Elsenstein \& H. JacoB, Felony Justice: An Organizational Analysis of Criminal Courts (1977) (study of Baltimore); M. Levin, Urban Politics and THE CRIminal Courts (1977) (study of Pittsburgh); Heumann \& Loftin, Mandatory Sentencing and the Abo- 
drop charges or deliver reduced sentences in return, not for the criminal defendant's waiver of his right to trial but rather for the defendant's waiver of his right to have a jury determine his guilt. Like cities that rely heavily on securing guilty pleas, cities that dispose of a significant number of cases by means of bench trials provide powerful incentives for the criminal defendant to waive the constitutional right to trial by jury. ${ }^{7}$ Defendants who waive their right to a jury trial are rewarded; those who demand a jury trial are punished. ${ }^{\mathbf{3}}$

In studying the jurisdictions that rely on bench trials, commentators have focused their attention on the question whether the bench trials defendants receive in exchange for waiving their constitutional right to a jury are "real" trials." The more fundamental question, whether incentives to waive the right to a jury are constitutional, has been largely ignored.

In considering the latter question, three lines of Supreme Court cases are relevant: the cases upholding plea bargaining, the cases considering unconstitutional conditions, and the cases involving "vindictive" sentencing. Many commentators claim to find irreconcilable conflicts among these lines of decisions. ${ }^{10}$ The well-established unconstitutional conditions doctrine seems to hold that penalties may not be imposed on, nor government privileges withheld from, those who exercise their constitutional rights. ${ }^{11}$ The decisions upholding plea bargaining, however, could be said to fly in the face of that doctrine. ${ }^{12}$ In plea bargaining, defendants are, in effect, penalized for demanding their right to a trial, or conversely, rewarded for waiving that right. As

lition of Plea Bargaining: The Michigan Felony Firearm Statute, 13 LAw \& Soc'y REv. 393 (1979) (study of Detroit); Mather, Some Determinants of the Method of Case Disposition: Decision-Making by Public Defenders in Los Angeles, 8 LAw \& Soc'Y REv. 187 (1973) (study of Los Angeles); Schulhofer, Is Plea Bargaining Inevitable?, 97 Harv. L. Rev. (forthcoming, No. 5 Mar. 1984) (study of Philadelphia); White, $A$ Proposal for Reform of the Plea Bargaining Process, 119 U. PA. L. REV. 439, 441-42 (1971) (study of Philadelphia).

7 For the forms in which these incentives may be offered see infra text accompanying notes $145-47$.

8 See infra text accompanying notes 109-10.

- Most observers have characterized these bench trials as "slow pleas of guilty." See infra note 161; see also White, supra note 6 , at 441-42. The most recent commentator disputes that characterization. Schulhofer, supra note 6 .

10 See Coffee, "Twisting Slowly in the Wind": A Search for Constitutional Limits on Coercion of the Criminal Defendant, 1980 Sur. CT. REv. 211, 220; Halberstam, supra note 2, at 1-35; O'Brien, Plea Bargaining and the Supreme Court: The Limits of Due Process and Substantive Justice, 9 HAstings Const. L.Q. 109, 134-50 (1981); Note, The Supreme Court 1969 Term, 84 HARv. L. REv. 1, 152-53 (1970) [hereinafter cited as Note, The Supreme Court 1969 Term]; Note, supra note 4, at 1400 (1970).

11 See infra text accompanying notes 25-27.

12 See infra text accompanying notes 64-97. 
one critic has said, "the Court [in upholding plea bargaining] has engaged in constitutional interpretation that is analytically untenable. . . . It has, in sum, sought to justify a result, rather than to apply neutral principles to the determination of the issue before it."1s

Most commentators find a similar conflict between the decisions upholding plea bargaining and the decisions invalidating vindictive sentencing. ${ }^{14}$ The vindictive sentencing cases, which raise issues remarkably similar to those in the plea bargaining cases, began with North Carolina v. Pearce. ${ }^{15}$.In Pearce, the Court held that a judge could not impose a harsher sentence after a remand and retrial than he had imposed after the original trial. ${ }^{16}$ The Court declared that such a sentence puts "a price on an appeal."17 Although Pearce appears consistent with the unconstitutional conditions cases, it is hard to reconcile with the plea bargaining cases.

This Comment examines these three apparently inconsistent lines of cases and establishes a framework for analyzing the constitutional dimensions of the right to a trial by jury. After examining the relevant case law in Part II, the Comment concludes that the right to a trial by jury is not an absolute right but rather one which can be impinged upon by valid state interests. ${ }^{18}$ To determine the constitutionality of state infringement upon the right to trial by jury a three-part test should be applied: is a constitutional right infringed?, is the infringement justified by a compelling state interest?, and is the method of promoting the compelling state interest the least restrictive alternative in terms of its impact on constitutional rights? Such an analysis produces results consistent with the results reached in the three lines of cases. The Comment applies this tripartite test to the state's provision of incentives to waive the right to jury and finds that such incentives can be constitutional provided that they are implemented by the least restrictive means. Part III explores the implications of that conclusion, arguing that a jury waiver system is not only less restrictive of sixth amendment rights than the plea bargaining system in that the jury waiver system preserves some trial rights, but also that a jury waiver system

13 Halberstam, supra note 2 , at 4.

14 See Coffee, supra note 10, at 220; Halberstam, supra note 2, at 6-18; Nemerson, Coercive Sentencing, 64 MinN. L. Rev. 669, 715-19 (1980); Schulhofer, Due Process of Sentencing, 128 U. PA. L. REv. 733, 780 (1980); Note, The Supreme Court 1969 Term, supra note 10, at 153-54.

16395 U.S. 711 (1969).

16 Id. at 724 .

17 Id.

18 The question of precisely how substantial the state interest must be is outside the scope of this Comment. 
accomplishes the state's purpose by substantially attaining the efficiency goals currently achieved through plea bargaining. Because a jury waiver system is both less restrictive than and an alternative to plea bargaining, the Comment concludes that plea bargaining should be declared unconstitutional.

\section{Rethinking a Doctrinal Trilemma}

In order to determine the constitutionality of incentives to waive the right to jury, one must first look for a principled basis upon which to harmonize the three seemingly conflicting lines of cases. Plea bargaining cases consider the constitutionality of providing criminal defendants with incentives to plead guilty. The guilty plea represents the defendant's decision not to contest the state's case against him and results in the loss of the many constitutionally guaranteed rights associated with the right to a jury trial. ${ }^{19}$ Despite its negative impact upon a criminal defendant's constitutional rights, plea bargaining has been held constitutional. ${ }^{20}$

In contrast, the Supreme Court has found the imposition of certain penalties on the right to appeal unconstitutional ${ }^{21}$ and has handed down a number of opinions limiting the state's ability to place conditions upon the exercise of constitutional rights. These cases appear to be completely inconsistent with the Court's acceptance of plea bargaining. Commentators have been nearly unanimous in their criticism of the Court's plea bargaining decisions. ${ }^{22}$ None has been able to reconcile the decisions with other doctrine, and most would probably agree with Professor Halberstam that the Court has merely "sought to justify a result."23

Indeed, the tone of the Court's decisions in the three areas is impossible to harmonize. Moreover, the welter of justifications the Court has offered for upholding plea bargaining suggests that the Court itself can find no principled basis for its holdings. The argument to be proffered here, however, is that the cases can be reconciled upon a principled ground, which has not heretofore been considered by the commentators but is consistent with other areas of Supreme Court adjudication.

The framework within which the Court's decisions may be reconciled is a "least restrictive alternative" analysis. This analysis, which is

19 See infra text accompanying notes 152-59.

${ }^{20}$ See infra text accompanying notes 69-79.

21 See infra text accompanying notes 122-39.

22 See supra note 10 . Some members of the Court have joined in that criticism. See, e.g., Bordenkircher v. Hayes, 434 U.S. 357, 367 (1978) (Blackmun, J., dissenting).

${ }^{33}$ Halberstam, supra note 2 , at 4. 
said to have arisen in the context of antitrust law, ${ }^{24}$ has three levels. At the first level, the question is whether a constitutional right has been impaired. If not, the law or governmental action is constitutional and the inquiry goes no further. If, however, a constitutional right has been impaired the question becomes whether a substantial, legitimate governmental interest is furthered by the law or action. If there is no such governmental interest, the law or action is unconstitutional. Even when a substantial, legitimate governmental interest can be demonstrated, the law is unconstitutional if there is another reasonable and adequate, but less restrictive, means to the government's objective. If no reasonable alternative exists, the law or action is constitutional, despite the incidental burden on constitutional rights. In sum, the government may justify an impingement upon constitutional rights only by demonstrating that it is the least restrictive means of achieving a substantial, legitimate state goal. The appeal of this analysis lies in its ability to effect a reasonable accommodation between conflicting interests.

Careful consideration of the three lines of cases supports the contention that the least restrictive alternative test successfully reconciles the case law that is relevant to evaluating state action that infringes the right to a jury trial. The next sections will examine each of these lines of cases.

\section{A. Unconstitutional Conditions}

An unconstitutional condition exists when the government "structure[s] an individual's choice in such a way that he will voluntarily forgo" one or more constitutional rights "in order to retain a different state-granted benefit."2s The unconstitutional conditions doctrine "holds that government may not condition the receipt of its benefits upon the nonassertion of constitutional rights even if receipt of such benefits is in all other respects a 'mere privilege." "26 Simply put, the doctrine means "that whatever an express constitutional provision forbids government to do directly it equally forbids government to do indirectly."27

The Supreme Gourt established the unconstitutional conditions doctrine in Frost $\mathcal{E}^{2}$ Frost Trucking Co. v. Railroad Commission. ${ }^{28}$ In

24 See Struve, The Less-Restrictive-Alternative Principle and Economic Due Process, 80 HARv. L. REv. 1463, 1463 n.1 (1967).

23 Note, supra note 4, at 1399.

${ }^{28}$ L. TRIBe, AMERIaAN Constitutional LAW $\S 10-8$, at 510 (1978).

27 Van Alstyne, The Demise of the Right-Privilege Distinction in Constitutional Law, 81 HaRv. L. REv. 1439, 1445-46 (1968).

${ }_{28} 271$ U.S. 583 (1926). 
that case, the Court held that due process was violated when the use of highways was conditioned upon conversion of private carriers to common carriers. The Court explained that its holding was necessary to protect constitutional rights and further noted that a direct impingement upon constitutional rights would be clearly unconstitutional. ${ }^{29}$ But what if the state, as in the present case, merely withheld "a privilege which may be vital" until the individual relinquished his constitutional rights?" The Court said that if that were allowed, "constitutional guaranties, so carefully safeguarded against direct assault, [would be] open to destruction by the indirect but no less effective process of requiring a surrender, which, though in form voluntary, in fact lacks none of the elements of compulsion." "31 The Court concluded that an individual in such a position "is given no choice, except a choice between the rock and the whirlpool."s2

Early decisions followed the reasoning of Frost $\mathcal{E}^{2}$ Frost. ${ }^{33}$ In Speiser $v$. Randall the Court held unconstitutional the denial of tax exemptions to veterans who refused to subscribe oaths. ${ }^{34}$ Echoing the theme of the Frost $\mathcal{E}$ Frost decision, the Court said: "To deny an exemption to claimants who engage in certain forms of speech is in effect to penalize them for such speech. Its deterrent effect is the same as if the State were to fine them for this speech."3s

In Shelton $v$. Tucker, the Court held that the state could not take away the jobs of teachers who refused to list every organization to which they had belonged in the past five years. ${ }^{36}$ Similarly, in Sherbert v. Verner, the Court invalidated the withholding of unemployment benefits from those who refused, for religious reasons, to work on Saturdays. ${ }^{37}$

Four years later, in Garrity v. New Jersey ${ }^{38}$ and Spevack $v$. $K l e i n,{ }^{39}$ the Supreme Court issued its broadest condemnation of imposing conditions upon constitutional rights. In Garrity, the Court held that police officers under investigation could not be threatened with the

29 Id. at 593.

so Id.

s1 Id.

32 Id.

ss See, e.g., Wieman v. Updegraff, 344 U.S. 183 (1952) (unconstitutional to condition public employment upon taking of oath denying affiliation with certain groups); Hannegan v. Esquire, Inc., 327 U.S. 146 (1946) (unconstitutional to condition mailing privilege upon compliance with content standards).

ss 357 U.S. 513 (1958).

ss Id. at 518.

36364 U.S. 479,490 (1960).

37374 U.S. 398,410 (1963).

38385 U.S. 493 (1967).

39385 U.S. 511 (1967). 
loss of their jobs for refusing to testify during an investigation of their actions. ${ }^{40}$ The Court said that coercion was "inherent in this scheme of questioning," and that therefore the statements made could not "be sustained as voluntary." "[w]here the choice is 'between the rock and the whirlpool,' duress is inherent in deciding to 'waive' one or the other." ${ }^{\prime 2}$

Spevack, announced the same day as Garrity, echoed the tone and holding of Garrity. Writing for the plurality, Justice Douglas held that an attorney could not be disbarred for refusing to produce financial records and testify at a judicial inquiry. ${ }^{43}$ The Court said that a person has a right to remain silent and "to suffer no penalty . . . for such silence." "44 The Court defined a penalty as any sanction which makes assertion of the constitutional right costly. ${ }^{45}$

Three years after Garrity and Spevack, however, the Court upheld a notice-of-alibi rule which allegedly conditioned the defendant's right to present a defense. ${ }^{46}$ In Williams $v$. Florida, a defendant was required to give the government notice that he planned to present an alibi defense. ${ }^{47}$ The Court upheld the notice requirement by finding that the dilemma faced by the defendant was essentially the same one he faced at trial: whether to call an alibi witness or not. The Court said this dilemma did not coerce him, within the meaning of the fourth and fifth amendments. ${ }^{48}$ Thus, even though the Court upheld the validity of the "condition," this case is consistent with the reasoning of other unconstitutional conditions cases as the Court did not find that the condition burdened the constitutional right.

In sum, the Court's unconstitutional conditions cases stand for the principle that withholding government benefits-whether use of the highways, money, jobs, or the right to practice law-in such a manner that an individual feels compelled to waive his constitutional rights is as unconstitutional as directly revoking those constitutional rights.

Some cases and commentators view the unconstitutional conditions doctrine as absolutely forbidding any government action that places conditions or qualifications upon the exercise of constitutional rights. For example, in Frost $\mathcal{E}$ Frost, the Court equated indirect with direct

to Garrity, 385 U.S. at $497-98$.

41 Id.

42 Id. at 498.

43 Spevack, 385 U.S. at 514.

44 Id. (quoting Malloy v. Hogan, 378 U.S. 1, 8 (1964)).

15 Id. at 515.

16 Williams v. Florida, 399 U.S. 78 (1970).

47 Id. at 80-86.

48 Id. at $82-84$. 
impingements upon constitutional rights and declared conditions upon constitutional rights invalid. ${ }^{49}$ Similarly, Professor Van Alstyne has examined the unconstitutional conditions cases and concluded that the Court has simply "appl[ied] the literal mandate of a given constitutional provision flatly to forbid government from conditioning its largess on any waiver of such a provision regardless of the circumstances. "\$50

Despite these sweeping statements, this Comment takes the position that the Court's decisions in the unconstitutional conditions area are consistent with a least restrictive alternative analysis. One commentator has argued for this conclusion, noting that decisions on the constitutionality of conditions have turned upon whether the condition "effectuate[d] a legitimate state interest" and whether the state-imposed condition was "narrowly drawn." Both of these elements are key to a least restrictive alternative analysis.

The Court explicitly used the least restrictive alternative analysis in Shelton $v$. Tucker, ${ }^{52}$ holding that the state could not fire teachers for refusing to list every organization to which they had belonged in the past five years. ${ }^{58}$ The Court noted that the state did have a legitimate interest in determining the competence of its teachers ${ }^{54}$ but found that there were "less drastic means for achieving the same basic purpose." Thus, the availability of a less restrictive alternative meant that the condition imposed failed at the third level and was therefore invalid.

In Sherbert $v$. Verner, the Court invalidated a state law that withheld unemployment benefits from those who refused for religious reasons to work on Saturdays. ${ }^{58}$ In doing so the Court distinguished Sherbert from a similar earlier case by holding that the regulation in Sherbert did not further a substantial, legitimate state interest. ${ }^{57}$ The condition in Sherbert, therefore, failed the tripartite test at the second level because of an insufficient state interest.

The categorical statements of Justice Douglas in Garrity v. New Jersey $^{\mathrm{68}}$ and Spevack $v$. Klein ${ }^{\mathrm{5 \theta}}$ could be viewed as sweeping away all

19271 U.S. at 593.

so Van Alstyne, supra note 27, at 1447 (emphasis added).

s1 Comment, Another Look at Unconstitutional Conditions, 117 U. PA. L. Rev. $144,156-57$ (1968).

82364 U.S. 479 (1960).

ss Id. at 480-82, 490.

st Id. at 485 .

65 Id. at 488 .

se 374 U.S. at 399-401, 408-10. (1961)).

s7 Id. at 408-09 (distinguishing Sherbert from Braunfeld v. Brown, 366 U.S. 599

88385 U.S. at $494-500$.

so 385 U.S. at 512-19. 
consideration of state interest and treating the individual's constitutional rights as an absolute to be safeguarded against any and all state infringement. The results in these cases are, however, consistent with a least restrictive alternative analysis. Both cases implicitly acknowledge the state's interest in obtaining evidence. "Our question is whether a State, contrary to the requirement of the Fourteenth Amendment, can use the threat of discharge to secure incriminatory evidence against an employee." Fo Furthermore, the Court said that the practice in Garrity was similar to that which had been struck by the Court in Miranda $v$. Arizona one term earlier. In Miranda, the Court had indicated that the safeguards which it proposed for the protection of the rights of the accused would not interfere unduly with the state interest in enforcing law and obtaining confessions. ${ }^{61}$ Similarly, recognition of a state interest is implicit in both Garrity and Spevack. Because the state's interest was not compelling enough to allow the interference with the accused's constitutional right, one need not decide whether a less restrictive alternative (the third step) was available.

When it upheld a condition on a defendant's right to present an alibi defense in Williams $v$. Florida, the Court stated that the defendant had not been coerced and therefore no constitutional right was impaired. ${ }^{62}$ Hence, this case too is explicable under the least restrictive alternative analysis; it is resolvable at level one.

Thus, the results in the Supreme Court's unconstitutional conditions cases fit with a least restrictive alternative analysis. The results indicate that a condition impinging upon constitutional rights will be upheld only if the state has a compelling interest in conditioning the constitutional right, and no less restrictive alternative is available to fulfill the state's need. . $^{\text {s }}$

0 Garrity, 385 U.S. at 499 (emphasis added). Spevack, which was decided on the same day as Garrity, was based on the same rationale: lawyers, like policemen, could not be compelled to incriminate themselves in criminal contexts. Spevack, 385 U.S. at 516. In Spevack, as in Garrity, the state had an interest in obtaining evidence. 385 U.S. at 516 (citing United States v. White). See also Garrity, 385 U.S. at 507 (Harlan, J., dissenting) ("The central issues [in Garrity] are . . . identical to those presented in Spevack v. Klein . . . ."). In both cases, the state's interest was in obtaining evidence and prosecuting criminals, not in hiring good state employees. Accord Spevack, 385 U.S. at 519-20 (Fortas, J., concurring).

384 U.S. 436, 481 (1966).

62 399 U.S. 78, 84-86 (1970).

os Least restrictive alternative analysis is widely used in unconstitutional conditions cases. See, e.g., Branti v. Finkel, 445 U.S. 507, 518-20 (1980) (first and fourteenth amendments protect persons from being discharged from state jobs because of political party; no state interest sufficiently important to permit conditioning public employment upon party affiliation); Zablocki v. Redhail, 434 U.S. 374, 388-91 (1978) (striking down statute conditioning marriage on proof that a parent has met child support obligations; no sufficiently important state interest, closely tailored); Memorial 


\section{B. Plea Bargaining Decisions}

Given the unconstitutional conditions cases, one might well have expected the Court to find plea bargaining unconstitutional. In the last analysis, plea bargaining is no more than the offering of incentives to waive trial rights guaranteed by the Constitution. ${ }^{84}$ The Court appeared to accept this evaluation when it invalidated a statutory form of plea bargaining in United States $v$. Jackson. ${ }^{65}$ The Court held that a statute providing that the death penalty could be imposed only after a jury trial put "an impermissible burden upon the exercise of a constitutional right." Je8 Justice Stewart's opinion stated that provisions the "purpose or effect" of which is to "chill the assertion of constitutional rights by penalizing those who choose to exercise them" are "patently unconstitutional." ${ }^{\circ 7}$ The Court found that "the evil in the federal statute was not that it necessarily coerce[d] guilty pleas and jury waivers but simply that it needlessly encourage[d] them."

Despite the holding and tone of the Jackson decision, the Supreme Court has proceeded in the fourteen years since that decision to uphold and justify the practice of plea bargaining. In Brady $v$. United States, ${ }^{68}$ the Court even upheld a guilty plea where, as in Jackson, demanding a jury trial could have resulted in a death sentence for the defendant. The Court explained that not every plea made for fear of the death penalty was invalid. ${ }^{70}$ Restating the holding of Jackson, the Court said Jackson merely required that guilty pleas be voluntary and intelligent. ${ }^{71}$ The Court refused to invalidate the practice of plea bargaining, asserting that the practice benefited both sides ${ }^{72}$ and that a guilty plea suggested some "hope for success in rehabilitation."7s

Not long afterwards, the Court discarded the rehabilitation rationale in North Carolina $v$. Alford. ${ }^{\mathbf{7 4}}$ In Alford, the Court upheld a plea

Hosp. v. Maricopa County, 415 U.S. 250 (1974) (struck down durational requirement as a condition for receipt of medical care by indigents; no compelling state interest, at 262-67; less drastic means available, at 267); Speiser, 357 U.S. at 529 (no compelling state interest).

o4 "Plea bargaining" as used in this Comment includes any incentive, implicit or explicit, to waive the right to a trial and enter a plea of guilty.

es 390 U.S. 570 (1968).

es Id. at 572 .

B7 Id. at 581.

${ }^{68} I d$. at 583 (emphasis omitted).

397 U.S. 742 (1970).

70 Id. at 747 .

71 Id.

72 Id. at $752-53$.

78 Id. at 753.

24400 U.S. 25 (1970). 
of guilty entered to avoid a possible death sentence even though the defendant adamantly asserted his innocence both before and after the plea. $^{78}$

The Court proffered another rationale for the constitutionality of plea bargaining in Santobello v. New York. ${ }^{76}$ Chief Justice Burger, writing for the Court, accorded great weight to the state's interest in the rapid and efficient disposition of cases effected by plea bargaining:

The disposition of criminal charges by agreement between prosecutor and the accused, sometimes loosely called 'plea bargaining,' is an essential component of the administration of justice. Properly administered, it is to be encouraged. If every criminal charge were subjected to a full-scale trial, the States and Federal Government would need to multiply by many times the number of judges and court facilities. ${ }^{77}$

The Chief Justice added that plea bargaining "is not only an essential part of the process but a highly desirable part for many reasons."78 Each of the reasons cited as making the practice desirable, however, related at least partly to the reason the Court claimed it was essential: it costs less and is faster than full-scale jury trials. ${ }^{\text {. }}$

In Bordenkircher $v$. Hayes the Court seemed to justify plea bargaining with one of the arguments used in Brady: a negotiated settlement was advantageous to both sides. ${ }^{80}$ In Bordenkircher, the Court rejected the claim that a prosecutor's adding charges against a defendant after the defendant refused to plead guilty violated due process. ${ }^{81}$ Justice Stewart wrote for the Court that in " the give-and-take negotiation common in plea bargaining between the prosecution and defense," " the two sides " 'arguably possess relatively equal bargaining power." "82 Thus, there was no danger "that the State might be retaliating against the accused" for exercising his constitutional right to a trial. $^{\mathbf{8 3}}$ So long as the accused is free to accept or reject the prosecution's offer, the Court reasoned, "there is no such element of punishment or retaliation." 84 The Court presumed accuracy in plea bargaining, claiming that defendants were "unlikely to be driven to false self-condemna-

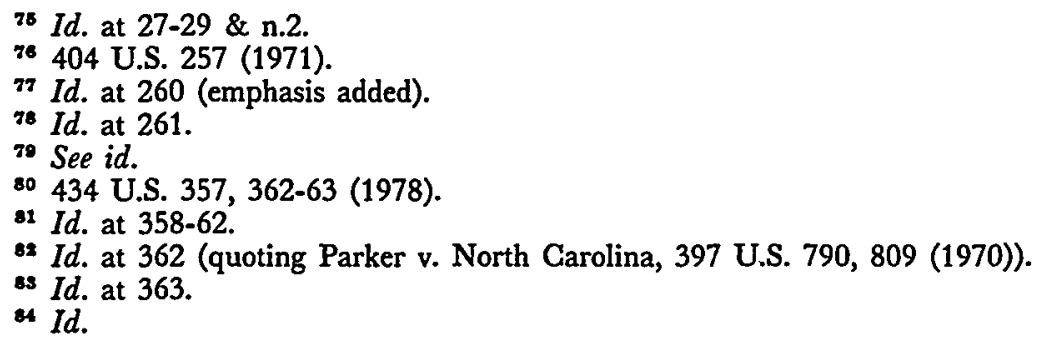


tion," given the procedural safeguards surrounding the plea. ${ }^{86}$ The Court did, however, caution zealous prosecutors that "there are undoubtedly constitutional limits" upon the exercise of the prosecutor's discretion in plea bargaining. ${ }^{86}$

Undermining the "negotiation" foundation for the constitutionality of plea bargaining, the Gourt upheld a statutory plea bargaining scheme in Corbitt $v$. New Jersey. ${ }^{87}$ In Corbitt, the Court validated a statute mandating a life sentence for those convicted of first-degree murder by a jury, but allowing the possibility of leniency for those who pleaded non vult to the same charge. ${ }^{88}$ The Court could "discern no element of retaliation or vindictiveness against Corbitt for going to trial." that "as long as [the] cases sustaining plea bargaining remain undisturbed" it could not declare this analogous situation unconstitutional. ${ }^{\mathbf{9 0}}$ The majority could not justify forbidding the legislature from doing that which the prosecutor had been allowed to do in earlier plea bargaining decisions. ${ }^{91}$

The Court's most recent affirmation of the practice of plea bargaining again endeavored to establish a principled basic for upholding the practice as constitutional. In United States $v$. Goodwin, the defendant had been indicted on additional charges after plea negotiations had broken down, and he had requested a jury trial. ${ }^{22}$ Despite the existence of unilateral government action similar to that in the vindictive sentencing cases, the Court upheld the addition of charges.

The Court stated that all of its cases had recognized one "basic-and itself uncontroversial-principle." ${ }^{\prime \prime s}$ That principle was that "[t]o punish a person because he has done what the law plainly allows him to do is a due process violation "of the most basic sort." "The critical issue was whether a "reasonable likelihood of vindictiveness" was present in the state action. ${ }^{85}$ In Bordenkircher, the Court recalled, it had held that "there was no. . . element of punishment in the 'give-

ss Id.

${ }^{86}$ Id. at 365 .

87439 U.S. 212 (1978).

${ }^{88} I d$. at $214-17$.

89 Id. at 223.

90 Id. at 223-24.

91 Id. at 224 n.14. Justice Stewart's concurrence in the judgment, id. at 227, and Justice Stevens' dissent, id. at 231, saw a difference between the more common forms of plea bargaining and statutory incentives to plead guilty.

92457 U.S. 368,370 (1982).

93 Id. at 372 .

o4 Id. (quoting Bordenkircher v. Hayes, 434 U.S. 357, 363 (1978)).

9s Id. at 373 . 
and-take' of plea negotiation." ${ }^{\text {"98 }}$ Similarly, the Court said that in this case the increased charges "in the context of plea negotiation" did not evidence "improper prosecutorial 'vindictiveness.' . . . [J] Just as a prosecutor may forgo legitimate charges already brought in an effort to save the time and expense of trial, a prosecutor may file additional charges if an initial expectation that a defendant would plead guilty to lesser charges proves unfounded." $"$ Thus, while affirming that an individual could not be penalized for exercising a constitutional right, the Court adamantly upheld the practice of plea bargaining.

The least restrictive alternative framework is consistent with the results in the cases upholding plea bargaining. Indeed, that the tripartite analysis would determine the constitutionality of plea bargaining was predicted by one commentator before any of those cases had been adjudicated. ${ }^{98}$

One might have thought otherwise after some of the early plea bargaining cases. In Brady v. United States, the Court claimed that one reason for allowing rewards for guilty pleas was that such pleas indicated a disposition amenable to rehabilitation. ${ }^{99}$ But the result in North Carolina $v$. Alford, ${ }^{100}$ upholding the guilty plea despite the defendant's claims of innocence, demonstrated that the constitutionality of plea bargaining did not turn on that factor. Alternatively, the language of some opinions might give one the impression that the cases turned on the existence of the "give-and-take" of negotiations inherent in plea bargaining. ${ }^{101}$ The actual insignificance of this factor, however, was revealed by the Court's decision in Corbitt $v$. New Jersey upholding a statutory form of plea bargaining. ${ }^{102}$

The remaining, albeit largely unspoken, justification for the holdings in the plea bargaining cases is that plea bargaining is the least restrictive means by which the government can achieve its substantial and legitimate interest in the cost-efficient disposition of criminal cases. Although the Court has not explicitly applied the least restrictive alter-

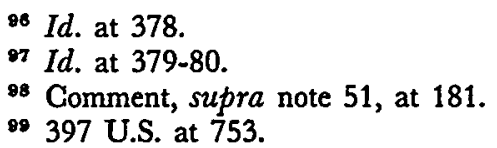

100400 U.S. 25 (1970). At issue in Alford was whether a guilty plea, which was voluntarily made, could be constitutionally accepted where the defendant nonetheless asserted his innocence. The Court held such pleas constitutional under certain circumstances: "In view of the strong factual basis for the plea demonstrated by the State and Alford's clearly expressed desire to enter it despite his professed belief in his innocence, we hold that the trial judge did not commit constitutional error in accepting it." Id. at 38 (footnote omitted).

${ }^{101}$ See, e.g., Bordenkircher, 434 U.S. at 363.

102439 U.S. 212 (1978). 
native analysis in this area, its decisions have answered each of the three questions that form the least restrictive alternative framework, and the answers the Court has provided have produced results that are coherent within the least restrictive alternative framework.

On the first level of the three part test, the Court seems to have recognized that defendants' constitutional rights are impaired by the plea bargaining process. In United States $v$. Jackson, the Court prohibited the needless chilling of the exercise of constitutional rights, ${ }^{103} \mathrm{im}-$ plicitly suggesting that the exercise of constitutional rights could be impaired for a proper purpose. Likewise, in Corbitt, the Court said that "not every burden on the exercise of a constitutional right . . . is invalid,"104 implicitly indicating that the plea in that case was valid despite the impingement upon constitutional rights. Not everything the Court has said supports the view that plea bargaining is an impingement upon constitutional rights. In Brady and Bordenkircher, the Court claimed that a plea bargaining system was advantageous to defendants. ${ }^{105}$ The Court has also asserted that defendants are "presumptively capable of intelligent choice" and are "unlikely to be driven to false self-condemnation." 106

The view that plea bargaining benefits defendants is unrealistic and has been less evident in recent plea bargaining cases. ${ }^{107}$ The reason the Court described plea bargaining as "advantageous" to defendants was that it allowed them to avoid the maximum punishment that they might receive if they exercised their right to trial. ${ }^{108}$ In some sense, the defendant does receive something for waiving his constitutional rights. As one commentator has pointed out, however, "a sentence differential is the essence of plea bargaining."109 Whether labeled "as a penalty or as a leniency, the result is the same: those who insist on a trial suffer substantially longer imprisonment than those who plead guilty." the most recent cases, Corbitt and Goodwin, the Court has accepted this reality and implicitly recognized that plea bargaining does trench on constitutional rights, leaving only the question whether the burden is a proper one. ${ }^{111}$

103390 U.S. at 582-83.

104 Corbitt, 439 U.S. at 218 (footnote omitted).

${ }^{105}$ See Bordenkircher v. Hayes, 434 U.S. 357, 361-62 (1978) (quoting Blackledge v. Allison, 431 U.S. 63, 71 (1977)); Brady, 397 U.S. at 752.

${ }_{108}$ Bordenkircher, 434 U.S. at 363.

${ }_{107}$ See, e.g., Goodwin, 457 U.S. at 378.

${ }^{108}$ See Brady, 397 U.S. at 752.

109 Halberstam, supra note 2, at 15.

110 Id.

111 The question the Court asked in both cases was whether "vindictiveness" was 
The Court has answered the second question of the least restrictive alternative analysis, whether a substantial and legitimate state interest is furthered by the impingement, with resounding affirmation. ${ }^{112}$ In Santobello, the Court clearly stated this conclusion for the first time. ${ }^{113}$ That opinion, written by Chief Justice Burger, echoed remarks he had made earlier in a speech to the American Bar Association. Ghief Justice Burger had emphasized the necessity of a high guilty plea rate and stated:

It is elementary, historically and statistically, that systems of courts-the number of judges, prosecutors and courtrooms-have been based on the premise that approximately 90 per cent of all defendants will plead guilty, leaving only 10 per cent, more or less, to be tried. . . . The consequence of what might seem on its face a small percentage change in the rate of guilty pleas can be tremendous. A reduction from 90 per cent to 80 per cent in guilty pleas requires the assignment of twice the judicial manpower and facilities-judges, court reporters, bailiffs, clerks, jurors and courtrooms. A reduction to 70 per cent trebles this demand. ${ }^{114}$

After accepting in Santobello the premise that plea bargaining was essential to further the government's interest in cost-efficient disposition of criminal cases, the Court never questioned the accuracy of that belief. Thus, in Bordenkircher the Court concluded that "by tolerating and encouraging the negotiation of pleas, this Court has necessarily accepted as constitutionally legitimate the simple reality that the prosecutor's interest at the bargaining table is to persuade the defendant to forgo his right to plead not guilty." 118 In Corbitt, the Court reiterated

the motive for the penalty. See Goodwin, 457 U.S. at 372-80; Corbitt, 439 U.S. at 22324.

112 The one exception is Jackson. See supra text accompanying notes 65-68. There the Court invalidated a statutory form of plea bargaining. The Court did not consider the relevance of a government interest in Jackson, which was the first of the plea bargaining cases. The holdings of subsequent cases indicate that Jackson has been overruled sub silentio. At least one commentator has recognized the possibility that Jackson may no longer be good law, stating that the Court's concern for "the practical, administrative needs of the system calls into question the continuing validity of Jackson. If avoidance of administrative overload is a legitimate state interest, then the Government misargued Jackson." Note, The Supreme Court 1969 Term, supra note 10, at 154 (footnote omitted). The Court's increasing willingness to consider the government's interest in restricting expenditures when deciding constitutional issues has been noted. See Frug, The Judicial Power of the Purse, 126 U. PA. L. Rev. 715 (1978).

113 See supra text accompanying note 77.

114 Burger, The State of the Judiciary-1970, 56 A.B.A. J. 929, 931 (1970) (text of speech given to the American Bar Association, August 1970).

118 Bordenkircher, 434 U.S. at 364. 
its recognition of the state's interest in "efficient criminal procedure"116 and concluded that harsher penalties for those who exercise their right to a trial were constitutional "as long as our cases sustaining plea bargaining remain undisturbed."117 Finally, elucidating the elements that distinguished plea bargaining from the vindictiveness cases, the decision in Goodwin allowed the imposition of a harsher sentence on one who exercised his rights because the decision to impose the penalty was grounded in a "societal interest in prosecution."118

On the third level of the least restrictive alternative test, the Court has not actively looked for alternatives to plea bargaining. In Santobello, the Court seemed to compare plea bargaining only with full-scale jury trials in considering efficiency. ${ }^{119}$ Deciding that the replacement of guilty pleas with "full-scale trials" would force the government "to multiply" present criminal justice system resources "by many times," the Court concluded that plea bargaining was "an essential component of the administration of justice."120 The use of the term "essential" suggests that the Court either saw no other alternatives or that it concluded without comment that any other alternative would not secure for governments the same magnitude of savings that plea bargaining had.

After Santobello, the Court did not look back. Since then it has reconsidered neither whether plea bargaining furthered a legitimate state interest nor whether alternatives are available. ${ }^{121}$ Thus, the Court's implicit answer to the third question of the least restrictive alternative test is that there are no viable alternatives to plea bargaining.

116 Corbitt, 439 U.S. at 220 n.9.

117 Id. at 223-24. The Corbitt Court also stated that "[w] hatever might be the situation in an ideal world, the fact is that the guilty plea and the often concomitant plea bargain are important parts of this country's criminal justice system." Id. at 222 n.12 (quoting Blackledge v. Allison, 431 U.S. 63, 71 (1977) (emphasis added)).

118 Goodwin, 457 U.S. at 380 n.11 (emphasis added).

119 See Santobello, 404 U.S. at 260.

$120 \mathrm{Id}$.

121 A recent case in a related area suggests that the Court still views the existence of alternatives as relevant to the issue of constitutionality. In Ludwig v. Massachusetts, 427 U.S. 618, 626 (1976), the Court held that a two-tier court system, in which no jury was available at the first level, put no burden on the exercise of the right to a jury. $I d$. at 621,626 . The majority did not consider the issue of alternatives because it believed that the procedure which allowed waiving the lower-tier trial and advancing to the second tier, by admitting certain findings of fact, did not deny a constitutional right. The dissent's dispute with the majority did not concern the validity of the incentive but rather the existence of a less restrictive alternative: allowing defendants to waive the first-tier trial completely. 


\section{G. Pearce, Blackledge, and "Vindictiveness"}

At about the same time that the Court was upholding plea bargaining, it was invalidating the imposition of penalties upon the exercise of the right to appeal on the grounds that such penalties were improperly "vindictive." In North Carolina v. Pearce, a defendant who successfully appealed a conviction and thereby won the right to a new trial received a harsher sentence from the same judge after being convicted a second time. ${ }^{\mathbf{1 2 2}}$ Ruling that "vindictiveness against a defendant" violates due process, the Court invalidated the higher sentence. ${ }^{123}$ The Court stated that "the imposition of such a punishment, "penalizing those who choose to exercise' constitutional rights, 'would be patently unconstitutional." "124 Accordingly, the Court fashioned a broad prophylactic rule that a judge must state reasons for imposing a more severe sentence after retrial. ${ }^{\mathbf{1 2 5}}$

In Blackledge v. Perry, the Court applied the Pearce rule to charges added by a prosecutor after a defendant exercised his right to a trial de novo. ${ }^{128}$ The Court reached that result despite its recognition that the prosecutor's interest in adding charges bore certain similarities to a prosecutor's interest in a plea bargaining situation. ${ }^{127}$

The Court soon distinguished from Pearce situations in which a second, harsher sentence was imposed by some authority other than the sentencing authority the defendant had faced in his first trial. Thus, in Colten v. Kentucky, the Court found no "possibility of vindictiveness" in a harsher sentence following a second trial in a two-tier court system. ${ }^{128}$ "The trial de novo represents a completely fresh determination of guilt or innocence. It is not an appeal on the record."'128 Likewise, in Chaffin v. Stynchcombe, the Court found no "hazard of vindictiveness" when a more severe sentence was imposed by a jury on retrial than had been imposed by the original jury. ${ }^{130}$

These cases appear to be consistent with the unconstitutional conditions cases but in direct conflict with the cases justifying plea bargaining. After all, one could argue that providing disincentives to exercising the right to appeal contributes to the same efficiency goals sought to be

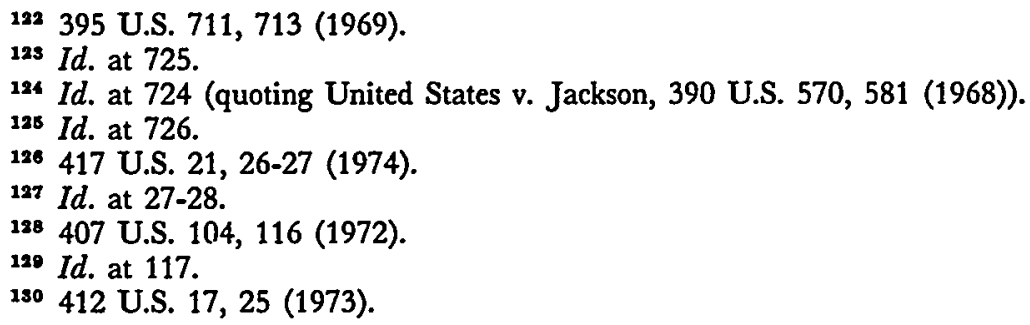


achieved through plea bargaining.

Some distinctions become clear, however, when the vindictiveness cases are examined in terms of the least restrictive alternative analysis. These cases can be viewed as constitutionally suspect at the second level of the analysis, given the Court's concern that vindictive sentencing may represent the expression of personal spite on the part of judge or prosecutor, rather than the implementation of a legitimate state interest in efficient disposition of cases. This concern can be seen in Pearce, in which the Court states that access to appellate review should be " kept free of unreasoned distinctions" "131 and expresses some concern about the difficulty of proving in any particular case that the result was motivated by personal spite. ${ }^{132}$ In the Court's view, there is an unacceptable danger that the penalty in such cases will be increased as a result of a personal grudge held by the prosecutor or judge for having been found in error and having to handle the same case twice. Thus, vindictive sentencing is seen as serving a personal rather than legitimate state interest.

The results of Chaffin v. Stynchcombe ${ }^{13 s}$ and Colten v. Kentucky, ${ }^{134}$ in which the Court allowed increased sentences or charges in circumstances that were identical except that the penalty was imposed by an authority other than the one that had imposed the original sentence or charges, lend support to this interpretation.

The Court's language also supports the hypothesized distinction. In Pearce, the Court said the critical element was the likelihood of a "retaliatory motivation."198 In Chaffin, upholding an increased sentence imposed by a different jury than had been reversed, ${ }^{186}$ the Court explained that "the jury, unlike the judge who has been reversed will have no personal stake in the prior conviction and no motivation to engage in self-vindication." 137 In a more recent statement on the meaning of "vindictiveness," the Court said in Goodwin that the issue was whether the Court could " "presume' an improper vindictive motive."138 Although it denied the defendant's claim in Goodwin, the Court added that an enhanced sentence or charge would be unconstitutional if a defendant could prove in the specific case that the decision "was moti-

131 Pearce, 395 U.S. at 724 (quoting Rinaldi v. Yeager, 384 U.S. 305, 310-11 (1966)).

${ }^{132}$ Id. at 725 n. 20.

193 412 U.S. 17 (1973).

134407 U.S. 104 (1972).

138 Pearce, 395 U.S. at 725.

${ }^{136}$ Chaffin, 412 U.S. at 25.

${ }^{137}$ Id. at 27 (emphasis added).

198 Goodwin, 457 U.S. at 373 (emphasis added). 
vated by a desire to punish him for doing something that the law plainly allowed him to do."199

\section{The Constrtutionality of a Jury Waiver System}

A least restrictive alternative analysis can be used to determine the constitutionality of state actions which impinge upon a criminal defendant's right to trial by jury. In the ordinary plea bargaining situation, the defendant is offered incentives which may lead him not to contest guilt and to waive all the trial rights guaranteed by the Constitution. In contrast, a jury waiver system protects certain trial rights although it does mean the relinquishment of the right to a jury determination of guilt. While plea bargaining has been declared constitutional, the constitutionality of a jury waiver system is still in doubt.

The Supreme Court has considered only two cases in which incentives were offered specifically to waive a jury, rather than to induce a guilty plea. In United States $v$. Jackson, ${ }^{140}$ the Court invalidated a statutory provision which permitted the death penalty to be imposed only by a jury; waiver of the right to jury effectively foreclosed the death penalty. This could be seen as the Court's rejection of jury waiver except for the fact that Jackson was decided before the Court recognized as legitimate the state interest furthered by plea bargaining and similar practices. The state interest issue was not even raised in Jackson.

In another case the Court was confronted with the claim that incentives to waive the right to jury were offered. Ludwig $v$. Massachusetts upheld a two-tier court system in which there was no right to a jury in the lower tier. ${ }^{141}$

Ludwig argued that the system conditioned his right to jury in three ways: by forcing him to spend the money necessary for two trials, by subjecting him to the possibility of a more severe sentence after the second trial than he would receive after the first, and by imposing the "increased psychological and physical hardship of two trials."142 The Court rejected all three arguments, primarily on the ground that Ludwig could have avoided any burden by employing the procedure of "admitting findings of fact," which allowed defendants to advance directly

130 Id. at 384 (emphasis added, footnote omitted). Lower courts have followed the Supreme Court's direction and looked for improper motivation. See, e.g., United States v. Gallegos-Curiel, 681 F.2d 1164, 1169 (9th Cir. 1982) ("It is only when prosecutorial actions stem from an animus toward the exercise of a defendant's rights that vindictive prosecution exists.").

140390 U.S. 570 (1968).

141427 U.S. 618, 626-28 (1976).

142 Id. at 626. 
to the second tier. ${ }^{143}$ Thus, the challenge to the two-tier court system failed because the Court concluded that no constitutional right had been burdened. The dissent's dispute with the majority seems to focus on the argument that the state had a less restrictive alternative: it could allow defendants to waive the first-tier trial completely. ${ }^{144}$ So in Ludwig, both the majority and dissenting opinions are consistent with the least restrictive alternative framework.

The constitutionality of jury waiver was not settled by Ludwig. In Ludwig, the Court found no impingement upon a constitutional right because of the availability of what it believed was a painless procedural maneuver by which one could avoid the penalty for demanding the right to jury. In a jury waiver system comparable to the plea bargaining model, the Court would have to recognize an impingement upon constitutional rights. Such a system could operate in any of the forms in which plea bargaining presently exists. Defendants could, for example, simply waive the right on their own initiative based on a perception that defendants usually receive a more lenient sentence after a bench trial conviction than after a jury trial conviction. (This perception has been instrumental in helping jurisdictions that rely on bench trials to attain their efficiency goals.) $)^{145}$ Alternatively, prosecutors could agree to drop charges in exchange for a jury waiver, or the judge could make an explicit sentencing concession, contingent on a finding of guilt. ${ }^{148} \mathrm{Fi}$ nally, the Corbitt decision suggests that legislatures could provide a sentencing "discount" within mandatory sentencing schemes or sentencing guidelines for those who waived the right to jury. ${ }^{147}$ In each of those situations, there is an impingement upon a constitutional right. It is the same impingement which operates in the plea bargaining context: those who exercise their constitutional rights are penalized with additional charges or a more severe sentence than those who plead guilty.

Since jury waiver does trench on constitutional rights, the issue, on the second level of the least restrictive alternative analysis, is whether jury waiver furthers a substantial, legitimate state interest. Here again the answer is the same as in the plea bargaining context. Bench trials

14 Id. As for the possibility of increased punishment, the Court said there was no danger of "vindictive" sentencing inherent in a two-tier system. Id. at 627 . As for the claim of additional delay, the Court found no proof that the two-tier system caused added delay. Id. at 629.

14t 427 U.S. at $634 \&$ n.1 (Stevens, J., dissenting).

${ }_{165}$ See, e.g., M. LEviN, supra note 6, at 84; Heumann \& Loftin, supra note 6, at 418-20. Schulhofer, supra note 6, manuscript at 90-91.

166 The Detroit study found some use of explicit sentencing concessions. Heumann \& Loftin, supra note 6 , at 417. 797.

${ }^{147}$ The possibility of a "discount" was raised in Schulhofer, supra note 14, at 
are less expensive than jury trials. ${ }^{148}$ The Court has recognized the state interest in efficient disposition of criminal cases ${ }^{148}$ and has even recognized that the maintenance of the criminal justice system would be jeopardized if defendants exercised their constitutional rights fully. ${ }^{\mathbf{1 5 0}}$ Thus, at the second stage of the analysis, it appears clear that jury waiver would advance a legitimate, substantial state interest in the efficient operation of the criminal justice system.

Under the least restrictive alternative analysis, jury waiver can constitutionally be used as a replacement for plea bargaining only if jury waiver attains substantially the same state interest and is less restrictive of defendants' constitutional rights than plea bargaining. ${ }^{181} \mathrm{~A}$ jury waiver system clearly passes this test, inasmuch as it requires defendants to waive fewer procedural rights than a plea bargaining system. Jury waiver defendants retain the right to refrain from self-incrimination, ${ }^{152}$ the right to present witnesses ${ }^{163}$ and confront opposing witnesses, ${ }^{154}$ and the right to the exclusion of evidence procured by unconstitutional means-for example, coerced confessions, ${ }^{165}$ uncounseled post-indictment interrogation ${ }^{156}$ and line-ups, ${ }^{157}$ identification procedures so suggestive as to violate due process, ${ }^{108}$ and illegal searches and seizures. ${ }^{158}$ Thus, as one commentator has observed, to hold that plea bargaining is constitutional while jury waiver is not is to adhere to the ironic proposition that one may not bargain away one's right to a jury unless one simultaneously bargains away all of one's other trial rights, as occurs in Court-approved plea bargaining schemes. ${ }^{160}$

Are the rights retained meaningful in a bench trial? For the most objective answer to that question, consider a worst-case scenario: a jury waiver system in which bench trials are perfunctory, nonadversarial af-

148 See infra note 187 and text accompanying notes 177-87.

140 Santobello v. New York, 404 U.S. 257, 261 (1971) ("Ieads to prompt and largely final disposition of most criminal cases"); Brady v. United States, 397 U.S. 742, 752 (1970) ("scarce judicial and prosecutorial resources are conserved").

1 so See Brady v. United States, 397 U.S. at 742, 752 \& n.10 (1970) (over threefourths of American criminal convictions rest on guilty pleas); see also Burger, supra note 114, at 931 ("The consequence of . . . a small percentage change in the rate of guilty pleas can be tremendous.").

${ }_{151}$ To date, no commentator has proposed a feasible, less restrictive alternative to both jury waiver and plea bargaining.

${ }_{162}$ Malloy v. Hogan, 378 U.S. 1 (1964).

183 Washington v. Texas, 388 U.S. 14 (1967).

164 Pointer v. Texas, 380 U.S. 400 (1965).

165 Miranda v. Arizona, 384 U.S. 436 (1966).

156 Massiah v. United States, 377 U.S. 201 (1964).

167 United States v. Wade, 388 U.S. 218 (1967).

158 Stovall v. Denno, 388 U.S. 293 (1967).

160 Mapp v. Ohio, 367 U.S. 643 (1961).

180 Schulhofer, supra note 6. 
fairs. (Many observers of jury waiver systems in fact claim that such bench trials are the norm and have characterized them as "slow pleas."161) Even in that situation, however, the prosecution would lose its weakest cases. The most recent study of a jury waiver system, in Philadelphia in 1982, found a significantly higher than average acquittal rate (thirty-three percent as compared to twenty percent) in cases in which no defense at all was raised. ${ }^{162}$ In a plea bargaining system, by comparison, the prosecution's weakest cases are prime cases for "bluffing." 163 Knowing he has no case, the prosecutor may bring enormous pressure to bear on the defendant by offering him a nearly irresistible "bargain." Thus, even the worst-case scenario for a jury waiver system is more favorable to defendants than a plea bargaining system. Furthermore, "slow pleas," are not inevitable. The recent Philadelphia study found that the trials are usually adversarial and defendants are usually well-represented. ${ }^{164}$

Jury waiver is thus less restrictive of constitutional rights than plea bargaining. Not only does the criminal defendant retain more of the procedural rights guaranteed by the Constitution, but also those procedural rights may in some cases result in fairer substantive results than a plea bargaining system can produce. ${ }^{165}$

A jury waiver system does seem to impinge upon the exercise of constitutional rights by providing a criminal defendant with incentives to waive his right to a jury trial. This system serves the state interest in the efficient disposition of criminal cases, an interest which the Court has recognized as legitimate and substantial. At present, this state goal is achieved in most jurisdictions by plea bargaining, a system which has a more restrictive effect upon the exercise of constitutional rights than would a jury waiver system. Thus, the key constitutional issue becomes

161 See J. EISENSTEIN \& H. JACOB, supra note 6, at 250 ("functional equivalent to the guilty plea"); M. LEviN, supra note 6, at 80; Heumann \& Loftin, supra note 6, at 420; Mather, supra note 6, at 190; White, supra note 6, at 441-42. The last four commentators characterize bench trials as "slow pleas."

162 Schulhofer, supra note 6, manuscript at 141.

${ }_{163}$ Alschuler, The Prosecutor's Role in Plea Bargaining, 36 U. CHI. L. REv. 50, 65 (1968). Prime cases for bluffing include those in which a vital witness is dead, missing, or unwilling to testify. Id.

184 Schulhofer, supra note 6, manuscript at 103-05.

${ }^{188}$ One could argue that plea bargaining is more flexible and can produce results better suited to individual circumstances. These sorts of advantages, however, can also be secured by a jury waiver system. Jury waiver, like plea bargaining, can be implemented in a variety of ways. Of course, even if jury waiver were inflexible, the fact would not necessarily militate against its use. Flexibility has been derided as "an advantage all lawless systems exhibit in comparison with systems of administering justice by rules. The utility of discretion must be balanced against the utility of pre-ordained rules ...." Alschuler, supra note 163, at 71 . 
the question whether jury waiver is an alternative to plea bargaining: does it serve the same state interest with sufficient efficiency to represent an alternative? If so, jury waiver would constitute a less restrictive alternative and plea bargaining, as a more restrictive practice, would be unconstitutional.

\section{The Jury Waiver Alternative and the Implications for Plea Bargaining}

This Comment has argued that the Court's decisions on plea bargaining and unconstitutional conditions are best understood in terms of a less restrictive alternative analysis. The argument will now be made that jury waiver is a less restrictive alternative to plea bargaining and, therefore, that the Court should declare plea bargaining unconstitutional. At the outset, it may seem perverse to explain or justify the Court's decisions upholding the constitutionality of plea bargaining in a way that makes plea bargaining unconstitutional. Indeed, such an interpretation would be perverse if the Court had considered and rejected bench trials as an alternative means of attaining the government's legitimate efficiency goals. The Court, however, has not considered bench trials. On the contrary, the Court in, for example, Santobello v. New York declared plea bargaining "an essential component of the administration of justice" because "[i]f every criminal charge were subjected to a full-scale trial," the resources of the criminal justice system would have to be "multipl[ied] by many times."168 That opinion confirmed assertions made by the Chief Justice in a speech several months earlier to the American Bar Association. He said that a decline in the guilty plea rate from ninety percent to eighty percent would double the need for jurors, as well as other court resources, and a decline to seventy percent would treble that need. ${ }^{167}$ Clearly, the Court never even considered bench trials as a possible alternative.

Demonstrating that the Court has been wrong in upholding the constitutionality of plea bargaining requires more than a showing that the Court has not considered the possibility that bench trials are an alternative to guilty pleas as a means of achieving governmental efficiency goals. It requires a showing that bench trials are a true "alternative." How close do bench trials come to achieving the efficiency levels reached by plea bargaining systems? Those who have researched bench trials in jury waiver systems and measured the length of bench trials

${ }_{168} 404$ U.S. 257, 260 (1971) (emphasis added).

107 Burger, supra note 114, at 931. 
have been in rough agreement. ${ }^{168} \mathrm{~A}$ Pittsburgh study concluded that guilty plea dispositions generally required one to fifteen minutes, bench trials usually consumed ten to thirty minutes, and jury trials took two to four days. ${ }^{169}$ A study of Baltimore was less precise. A hypothetical bench trial synthesizing the researchers' observations consisted of a relatively complicated armed robbery case in which a motion to quash was made with arguments from both sides, five witnesses including the defendant testified, the judge "frequently" posed questions to the witnesses, and brief closing arguments were made. ${ }^{170}$ The trial was said to consume fifty minutes. ${ }^{171}$ Although that must have been a more serious case, with more testimony, than the average trial, the author claimed that a "normal bench trial" required one to two hours, while jury trials lasted "at least one full day."172 According to one source cited in a recent study of Detroit, where bench trials were used extensively only for cases involving firearms, guilty pleas took fifteen minutes, bench trials thirty minutes, and expeditious jury trials one day. ${ }^{173}$ The large time savings in a bench trial were attributed to time saved by no jury selection, no opening arguments, brief examination of witnesses, and "no tricks . . . because there's no jury."174 The most recent study, in Philadelphia, roughly confirmed the previous findings. Based on data from 340 dispositions, ${ }^{175}$ that study found that guilty pleas consumed twenty minutes and bench trials forty-five minutes. ${ }^{178}$

In sum, guilty pleas seemed to require about fifteen to twenty minutes and bench trials about thirty to forty-five minutes, usually about double the time of a guilty plea. The author of the Philadelphia study pointed out that this comparison is not completely accurate. ${ }^{177}$ Unlike the other studies, the Philadelphia study also measured the de-

168 See J. Eisenstein \& H. JACOB, supra note 6, at 72 (elaborate hypothetical bench trial said to be possible in 50 minutes); $i d$. at 250 (jury trials typically take at least one day, and normal bench trials take one to two hours); M. LEVIN, supra note 6, at $321 \mathrm{n} .1$ (average guilty plea takes one to fifteen minutes, "a brief informal trial" takes between ten minutes and two hours, a full-length nonjury trial takes one to two days, and a full-length jury trial takes two to four days); Heumann \& Loftin, supra note 6 , at 417 (average jury trial takes one to two days, average guilty plea takes fifteen minutes, average bench trial takes one-half hour); Schulhofer, supra note 6 , manuscript at 159 (average guilty plea takes about twenty minutes, average bench trial takes fortyfive minutes).

169 M. LeVIN, supra note 6 , at 321 n.1.

$170 \mathrm{~J}$. Eisenstein \& H. JACOB, supra note 6, at 68-72.

171 Id. at 72 .

172 Id. at 250.

173 Heumann \& Loftin, supra note 6, at 417.

124 Id.

175 Schulhofer, supra note 6, manuscript at 53.

178 Id. manuscript at 159.

177 Id. manuscript at 58, 157-59. 
lay time involved in either type of disposition. ${ }^{178}$ That time, measured at thirty-five minutes for either type of disposition, consisted of such delays as waiting for a defendant to be brought to the courtroom, waiting for an attorney to arrive at the courtroom, and handling the administrative details involved in the disposition of criminal cases. ${ }^{179}$ After adding the delay time to the actual disposition time, the Philadelphia study found that guilty pleas required fifty-five minutes and bench trials took about eighty minutes. ${ }^{180}$ Undoubtedly, the other courts, which spent roughly the same amount of time as Philadelphia on actual dispositions, experienced similar delays. Using the Philadelphia results as a model, it now appears that bench trials consumed forty-five percent more time than guilty pleas.

That data implies vastly different results from those which the Court has reached. Although the Court said that the abolition of plea bargaining would require a multiplication of resources by many times, ${ }^{181}$ and the Chief Justice said more specifically that a reduction in guilty pleas from ninety percent to seventy percent ${ }^{\mathbf{1 8 2}}$ would require a tripling of resources, ${ }^{183}$ the same reduction would require only a nine percent increase in resources if bench trials were used as the replacement for guilty pleas. ${ }^{184}$ Clearly, the results of the abolition of plea bargaining need not be the catastrophe that the Court has envisioned.

Although the disparity between the Court's prognostications and the nine percent figure is great, even the nine percent figure overestimates the necessary increase. It does not consider the large fixed cost incurred in either type of disposition before the case even comes to

178 Id. manuscript at 59-61.

179 Id. manuscript at 59-60.

$180 \mathrm{Id}$. manuscript at $60,102$.

182 Santobello, 404 U.S. at 260.

182 See supra text accompanying note 114 (quoting Chief Justice Burger's speech to the American Bar Association). One should, however, note that if plea bargaining were abolished, the guilty plea rate would probably fall below seventy percent but not to zero. Of the 549 cases included in the Baltimore study, forty-five percent of those not dismissed were disposed of by guilty plea (percentage calculated from figures in $\mathrm{J}$. EISENSTEIN \& H. JACOB, supra note 6, at 233) despite the fact that researchers found little evidence of plea bargaining, J. EISENSTEIN \& H. JACOB, supra note 6, at 77. Similarly, the Philadelphia study found that in 1981, forty-five percent of all dispositions on the merits were achieved by guilty pleas, Schulhofer, supra note 6 , manuscript at 62, despite the rarity of meaningful plea bargaining. Id. manuscript at 67-72.

18 B Burger, supra note 114 , at 931.

184 See Schulhofer, supra note 6, manuscript at 159 . Even if the guilty plea rate were to fall by forty percentage points, as note 182 suggests might happen if plea bargaining were abolished, only an eighteen percent increase in resources would be needed. This second estimate is still strikingly smaller than the Court's figure of 200 percent. 
court for final disposition. ${ }^{185}$ There may be preliminary hearings, earlier appearances before the court when the case was postponed, presentence investigations, deferred sentencing hearings, plus a minimum amount of preparation time for the attorneys. ${ }^{186}$ This fixed time, which would be difficult to measure, should be added to each form of disposition in order to determine how significant the marginal cost of providing a bench trial (fifteen to twenty-five minutes depending on the study used) actually is. The larger the fixed cost is, the lower the percentage increase necessary to provide bench trials where before there were guilty pleas. Thus, if the pre-disposition fixed costs adumbrated here were added to the fixed delay costs, the increase in resources necessary to reduce the guilty plea rate from ninety percent to seventy percent, becomes even less than the nine percent figure calculated above. ${ }^{187}$

Where the Court saw a financial mountain of resistance to the abolition of plea bargaining, there was perhaps more than a molehill but certainly not the unscalable peaks it envisioned. An "alternative" to the present system that would require a multiplication of resources by many times may fairly be said not to be an alternative at all. But an alternative that would require a percentage increase of resources in the tens instead of hundreds of percentage points deserves the Court's thoughtful consideration. Such a consideration should lead the Court to view bench trials as a feasible "alternative"188 to plea bargaining. With an alternative in existence, plea bargaining is no longer a necessary evil: it becomes both an unnecessary and an unconstitutional evil.

\section{Conclusion}

A least restrictive alternative framework is a principled framework in which to rationalize the Court's decisions on the constitutionality of

185 Schulhofer, supra note 6, manuscript at 59-61, 159-159a.

188 Id.

187 Although the Court has failed to consider the efficiency of bench trials, the Court's calculations regarding the large increase in resources that would be necessary to provide jury trials have been borne out by the empirical studies. See supra text accompanying notes $169 \& 172-73$. If eight hours were necessary for an average jury trial, jury trials would cost about thirty-two times more than guilty pleas that average fifteen minutes each. Even if the time for guilty pleas were set at one hour after factoring in delay time, jury trials would still cost eight times what guilty pleas cost.

${ }_{183}$ Besides the analysis supra, text accompanying notes 168-87, the Court could properly conclude that jury waiver is an "alternative" to plea bargaining based on the bare fact that little or no plea bargaining was found in Baltimore, J. EISENSTEIN \& $H$. JACOB, supra note 6 , at 77 , or in Philadelphia, Schulhofer, supra note 6 , manuscript at 65-72. If these cities, which face crime problems and budget constraints as serious as those troubling other American cities, could manage without plea bargaining, the Court could reasonably infer that other cities could do without plea bargaining as well. 
governmental incentives to waive constitutional rights. Applying that framework to a jury waiver system, one concludes that such a system is constitutional.

A jury waiver system may properly be seen as a true alternative to a plea bargaining system by substantially attaining the state's efficiency goals. Since a jury waiver system is also less restrictive of constitutional rights than plea bargaining, the analysis mandates that plea bargaining be declared unconstitutional. 
. 